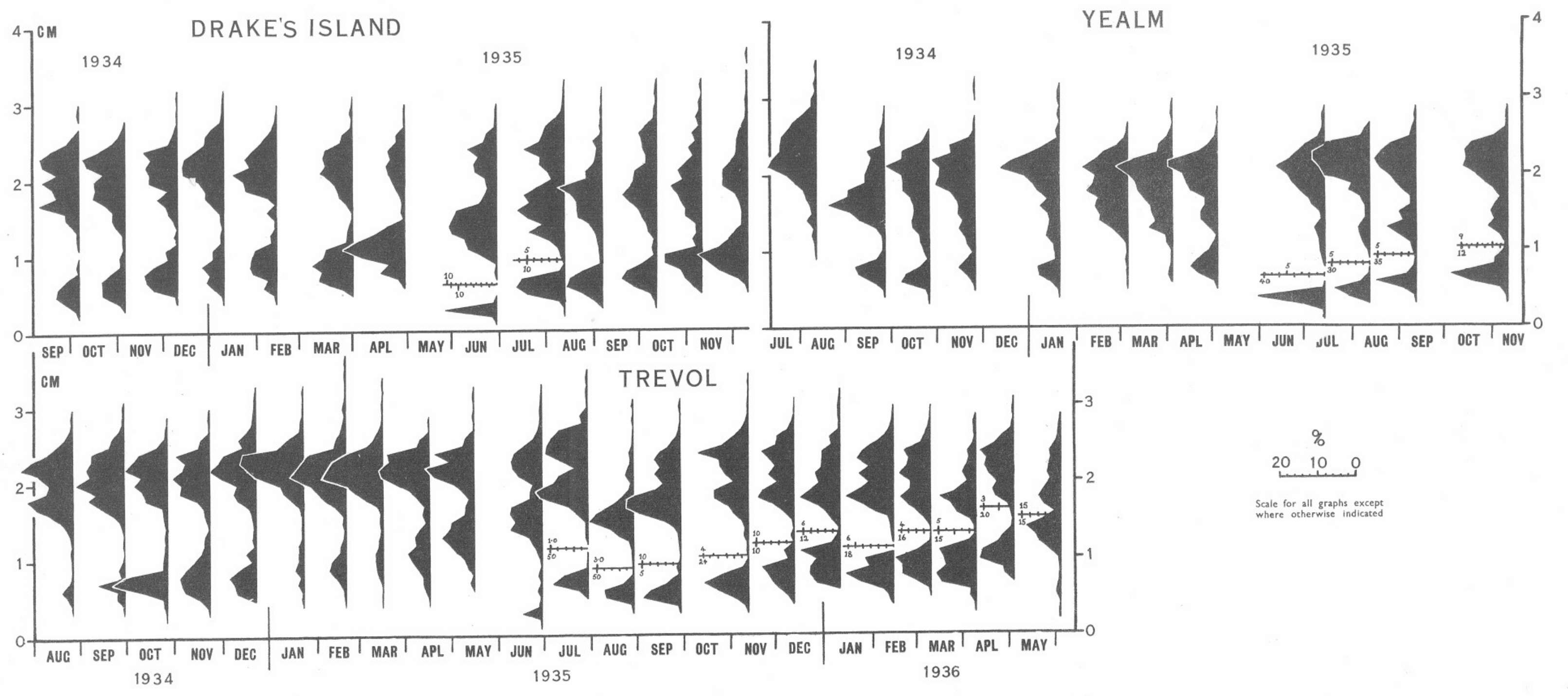




\title{
The Biology of Littorina littorea. Part I. Growth of the Shell and Tissues, Spawning, Length of Life and Mortality.
}

\author{
By \\ Hilary B. Moore, Ph.D., \\ Marine Biological Laboratory, Plymouth.
}

With Plate III and 10 Figures in the Text.

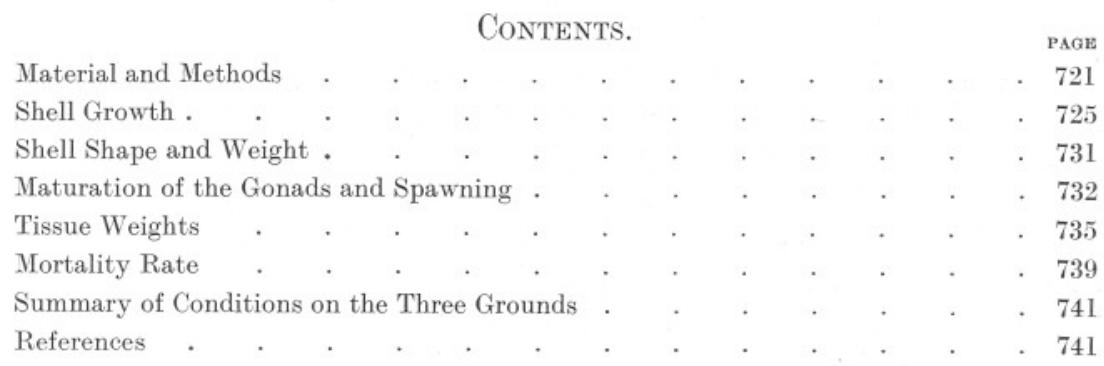

Material and Methods.

The Periwinkle, Littorina littorea (L.), is one of the most abundant gastropods on the shore, and can live under widely varying conditions. It is found on clean, alga-covered rocks, among small stones, on gravel, on soft mud, and rarely even on sand. It ranges from about high water of neap tides to extreme low water of spring tides, and in some places even slightly below this, although in most localities it is restricted to a much smaller part of the tidal zone. It occurs also from shores with high wave-exposure to sheltered and even polluted estuaries, where it is tolerant of considerable lowering of the salinity. The material for the present study was collected at intervals throughout 1934-1936 from three localities near Plymouth, the details of which are as follows.

Trevol. Level : mid-tide level. A mud flat in the middle of St. John's Lake, opposite Trevol Pier. The mud is soft, so that a man will sink six to twelve inches into it, and there is a sprinkling of dead shells on the surface. The smaller winkles in particular tend to cluster on these dead shells. In some parts there is a growth of Zostera and Enteromorpha, but on most of the ground there is no macroscopic algal growth.

Drake's Island. Winkles are abundant from about mid-tide level to between mean low water of neap tides and mean low water of spring 
tides. The area used for collection was a stony beach on the north side of the island, with a medium amount of Fucoid growth.

Misery Point, Yealm. The winkles are abundant about mean low water of spring tides, and very few are found above mean low water of neap tides. There is very little Fucoid growth, but the winkles cluster in very large numbers on such few fronds of Fucus as are present. There is a tidal stream of about $2 \frac{1}{2}$ knots past the point.

Single samples were also taken from four other localities for shape determinations (see p. 732).

A certain number of winkles are collected by fishermen from the Trevol and Yealm grounds, but mostly from slightly different positions from those used in the present work, so that the populations may be taken as being little influenced by them. There is no such collection on Drake's Island.

Two methods of sampling were used. The first, that of hand picking all the winkles visible on a fairly large area, yielded large numbers, but was not fully representative of the smaller sizes below about one centimetre in height. The second method consisted in sieving the entire surface sample of ground from a known area, down to about five centimetres in depth, but owing to the large amount of extraneous material collected this method could be applied to small areas only-in practice usually one square metre. The second method yielded a representative sample of all sizes of the population, with as many of the small sizes as were needed for measurement but did not contain anything like the one to two thousand of the larger sizes which were required. Where possible, therefore, the two methods were used and the size distribution of the larger sizes as determined from the large hand-picked sample combined with that for the smaller sizes as determined from the surface sample in the proportion indicated in the latter. This procedure was readily applicable on the mud at Trevol, where it was used from July, 1935, onwards. It was more difficult on the stony ground at Drake's Island and the Yealm, where it was applied on special occasions only ; in general, only handpicked samples were taken from these two grounds with the result that, while the mean height of the first year shells as determined from these samples is correct, their numbers relative to the older ones are too small. The same applies to the sample taken at Trevol before July, 1935.

The height of the smaller shells was measured to the nearest millimetre with sliding callipers. For the larger shells it was found necessary, if a second year peak was to be differentiated with any certainty in the size distribution curves, to measure between one and two thousand shells in each sample. For this purpose a machine was used which measured the height of each shell, and besides indicating its height in millimetres, counted the total number measured in each millimetre group. The average 
numbers measured per sample for each ground were 1,348 for the Yealm, 1,601 for Trevol and 706 for Drake's Island, the numbers being kept smaller at the latter locality owing to the limited size of the ground and the fear of seriously depleting its stock.

Samples were taken from each ground at approximately monthly intervals, and were used for size distribution analyses and also for shell and tissue weight determinations and for gonad examinations. At first twenty animals were taken at each millimetre interval of height and, after being boiled for about two minutes, the animals were removed from their shells with a pin, the twenty shells and twenty bodies being placed in weighed glass dishes. They were then dried in a boiling-water oven, the shells for one day and the tissues for three, and weighed. Monthly curves were thus obtained for each locality showing the relation of shell and tissue weights to shell height. After twelve months it was shown conclusively that there was no seasonal variation in shell weight, so the latter determinations were discontinued, and the mean values for the year assumed to hold for all further calculations (Fig. 6). In this part of the work the two sexes were not distinguished, but from July, 1935, onwards the material from Trevol was examined on extraction from the shells, and twenty each of males and females were set aside from each millimetre group for weighing. It was found to be quite possible to distinguish the sexes by the presence or absence of a penis, except in very small immature specimens, although in the non-breeding period the penis is reduced to a very small size.

From December, 1935, regular samples were examined from Trevol, and a few also from the other grounds, for the condition of the gonads. Smears were taken from the ovary and oviduct of the females and from the vesicula seminalis of the males, and the condition of the genital products recorded. In most cases samples were taken representative of each distinguishable year group on the ground in question.

Finally, for the determination of the growth of shells which were too old to come within the limit of distinguishable year-groups in the size distribution analyses, a number of winkles were collected from Drake's Island, marked at the apex with cellulose paint, and their lip notched with a carborundum wheel. They were then released on the ground from which they were taken and at intervals they were collected and the height and the spiral increment to the lip from the notch measured for each individual. They were then returned to the shore again as quickly as possible, care being taken to avoid high temperatures during the period when they were away from the shore; it was usually found possible to collect them one day and to return them the next. The process of marking was calculated to produce as little disturbance as possible. The shells were rapidly dried in a current of air from an electric fan ; the apex of each was then 
dipped into cellulose paint and they were replaced in the air current until the paint was dry enough to handle. The edge of the shell was then notched with an electrically driven carborundum stone, and the winkles returned to running sea-water, the whole process not lasting more than

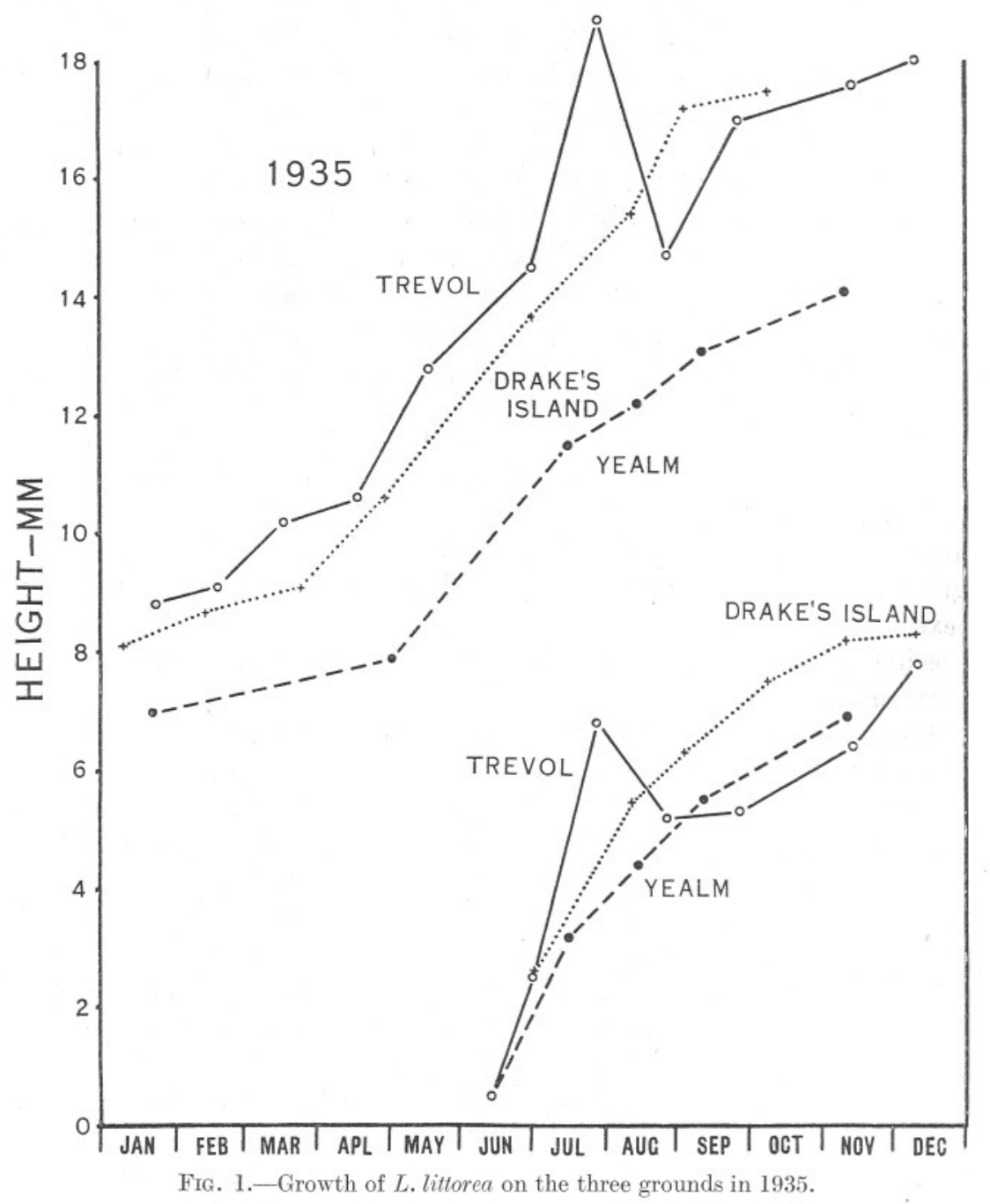

half an hour. Cellulose paint was found to last fairly well on the shore and not to need renewing for several months at least.

In the first place 2,695 marked winkles were released on Drake's Island in September, 1934, and the returns obtained ranged from three to four hundred in the first few months down to about a hundred at the end of a 
year. Of these winkles, 1,700 whose sex was not determined, were marked with blue paint. The sex of the remainder was determined by relaxing them in a dilute solution of pilocarpine hydrochloride and noting the presence or absence of a penis. The males were then painted green and the females red. The measurements of the red and the green shells were kept separate for the determination of the relative growth-rates of the two sexes, but all colours were taken together for the general growth results.

\section{Shell Growth.}

The size distribution curves for the three grounds are shown in Plate III. It should be noted that the proportion of first-year shells to older ones is too low up to a height of about one centimetre on all grounds except for

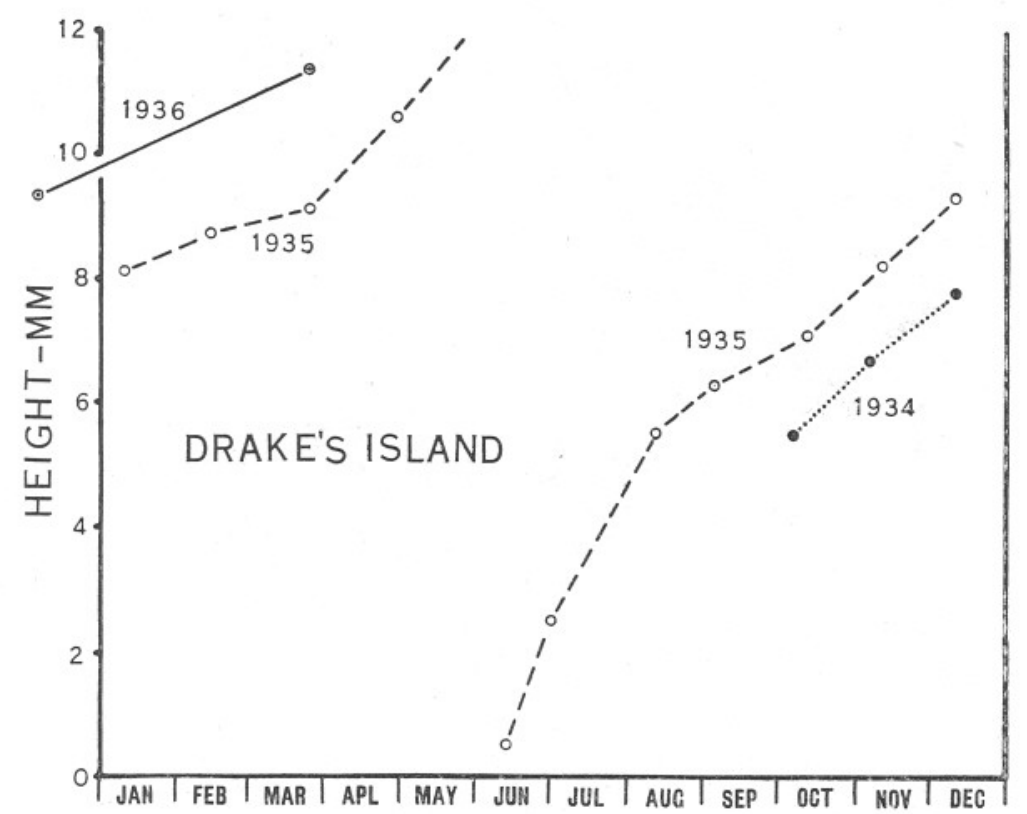

FIG. 2.-Comparison of the growth of L. littorea on Drake's Island in different years.

the 1935 brood at Trevol. From these size distribution figures the mean size of the first and second year groups was determined wherever possible for each sample, and from these the growth curves shown in Figs. 1, 2 and 3 were drawn. Fig. 1 shows the relative growth in height on the three grounds in 1935. In their first year, growth on Drake's Island was considerably faster than that at the Yealm, while the growth at Trevol was rather erratic. For the second year animals, however, the rates for Trevol and Drake's Island are very similar while that for the Yealm is definitely less. The figures serve also to show the variation in growth on the same 
ground in different years (Figs. 2 and 3). At the Yealm there is no significant difference in the growth-rates in the years 1934, '35 and '36, but at Drake's Island the rate is definitely greater in 1936 than in 1935 and in 1935 than in 1934. At Trevol the reverse results are found, and the

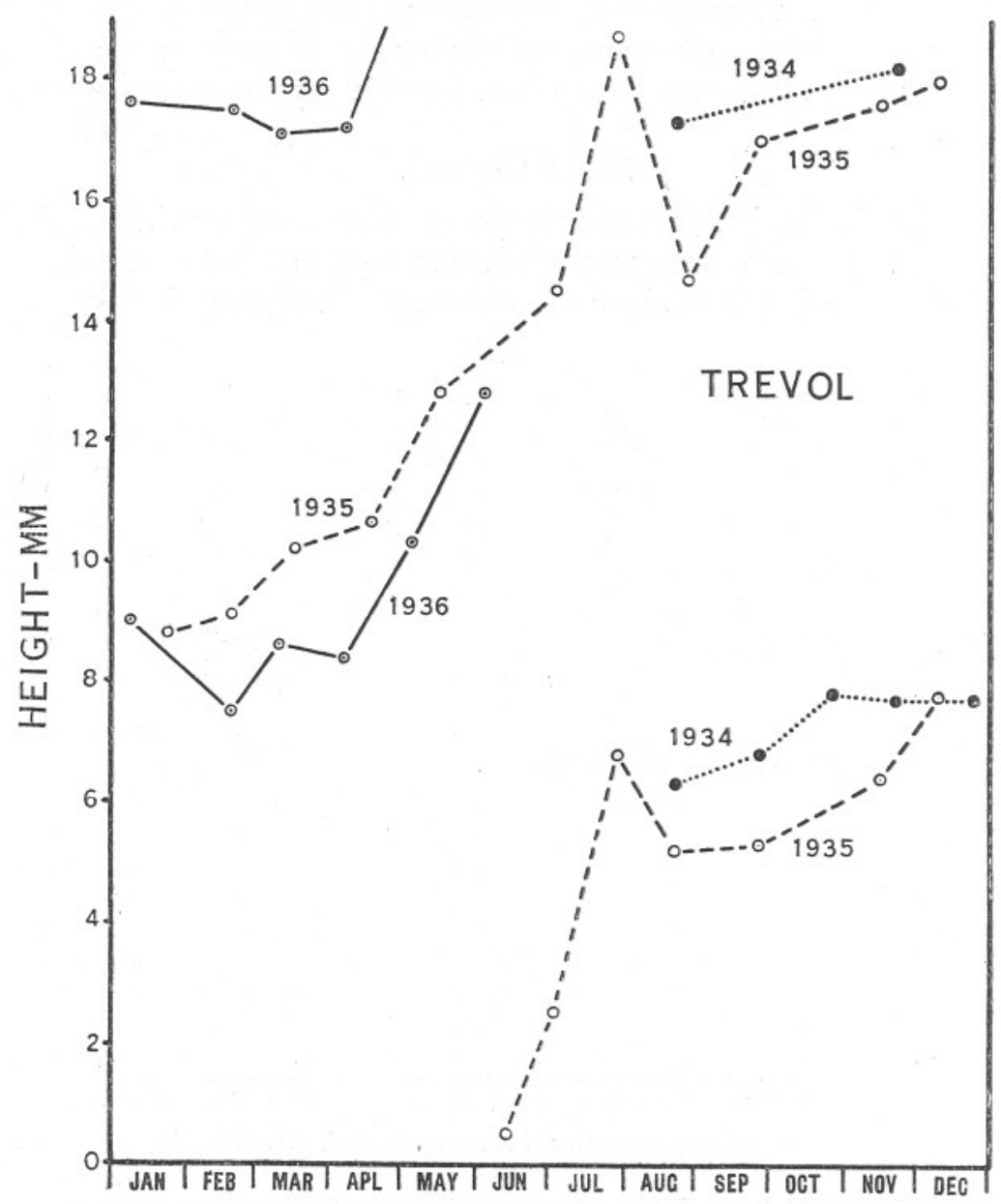

FIG. 3.-Comparison of the growth of $L$. littorea at Trevol in different years.

rate is less in 1936 than in 1935 and less again in 1935 than in 1934 . The differences in successive years at Drake's Island and Trevol are of an order which might well be considered significant in correlation with, for example, sea temperature changes in the different years, and yet the winkles on the 
different grounds show entirely different variations, thus emphasizing the danger of drawing conclusions from the study of a population from a single locality or for a single year only. The possible connexion between the observed local differences and the habitat is discussed later.

The size distribution figures are useful only up to an age of about two years, after which the successive peaks overlap too much to be distinguished, so for the growth of the larger sizes a method of individual marking was necessary. Such a method is possible only on a ground which is close to the laboratory, and where collecting is easy and there is

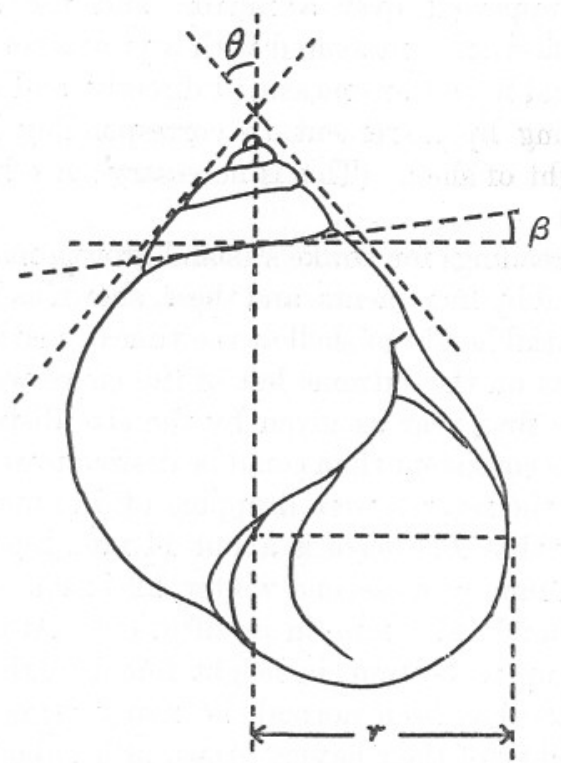

FIG. 4.-Diagram of L. littorea showing shell angles (see text).

no risk of the brightly coloured shells being picked up by fishermen, and for all these Drake's Island was ideal. A small number of marked shells were released at the Yealm also, but the returns were poor, and the results served only to confirm the much slower growth-rate there than at Drake's Island.

The relation between the amount of growth measured in a spiral direction on the lip of a shell and the corresponding increase in the height of the shell is dependent on two fundamental shell angles, $\theta$ the halfapical angle (Fig. 4), and $\alpha$ the spiral angle (Moore, 1936, p. 72). $\theta$ is easily obtained by direct measurement, but $\alpha$ is more readily obtained from the formula

$$
\tan \alpha=\frac{2 \cdot 72 \sin \theta}{\log \mathrm{R}}
$$

where $\mathrm{R}=$ the ratio of the diameters of two successive whorls. The formula 
for the length of a plane logarithmic spiral is $\frac{1}{r}=\sec \alpha$, where $l=$ the length, and $\mathrm{r}=$ the vector radius (Fig. 4 ). In the case of a spiral projected on to a cone such as we have in Littorina, a correction must be made, so that

$$
\frac{\mathrm{l}^{\prime}}{\mathrm{r}}=\sec \alpha \cdot \sec \beta
$$

where $\mathrm{l}^{\prime}=$ the spirally measured length, and $\beta$ an angle derived from $\alpha$ and $\theta$, but most readily obtained by direct measurement (Fig. 4). If the shell is supported over a mirror, and the angle between a suture and its reflection is measured with a protractor, this is equal to $2 \beta$. The radius and height are measured directly, and so a curve can be constructed relating lip increment to corresponding height increment at any given height of shell. (This is necessary since both $\alpha$ and $\theta$ vary with shell height.)

The successive readings for Drake's Island growth material were in the form of heights and lip increments, and these, shown as height increments plotted against initial height of shell at the time of marking, are shown in Fig. 5. The points on the extreme left of the curve were obtained from the growth in the first year as given by the size distribution analyses. The results are less consistent than could be desired towards the end of the experiment when the returns were dropping off in number, but they are sufficient to show that L. littorea is about $14 \mathrm{~mm}$. high in December of its first year, $17 \cdot 4 \mathrm{~mm}$. in its second winter, $22 \cdot 4 \mathrm{~mm}$. in its third winter, $25.4 \mathrm{~mm}$. in its fourth, $27.3 \mathrm{~mm}$. in its fifth, $\epsilon$ tc. At this rate the very large individuals up to $36 \mathrm{~mm}$. in height found in this locality would, if their growth-rate has been normal, be many years old, but there is always the possibility of their having grown at an abnormally high rate, perhaps as a result of parasitization by cercariae. It may, however, be mentioned that Waters (1890) says that he kept individuals living for ten years in an aquarium.

In the above calculations the possibility of a different growth-rate in the males and the females has not been considered, since it would obviously have been impossible to determine the sex of the sixty thousand shells measured. The experiment on the growth of winkles of known sex on Drake's Island shows clearly, however, that there is such a difference. If we take the ratio of the amount of growth in the males to that in the females in each millimetre group at each period of collection, and from this obtain a mean value for each period, we get the results which are shown in Table I (p. 730).

Excepting the first month when the amount of growth was so small as to be difficult to measure, and therefore not very reliable, there is in all cases a definitely greater rate of growth in the females than in the males. 


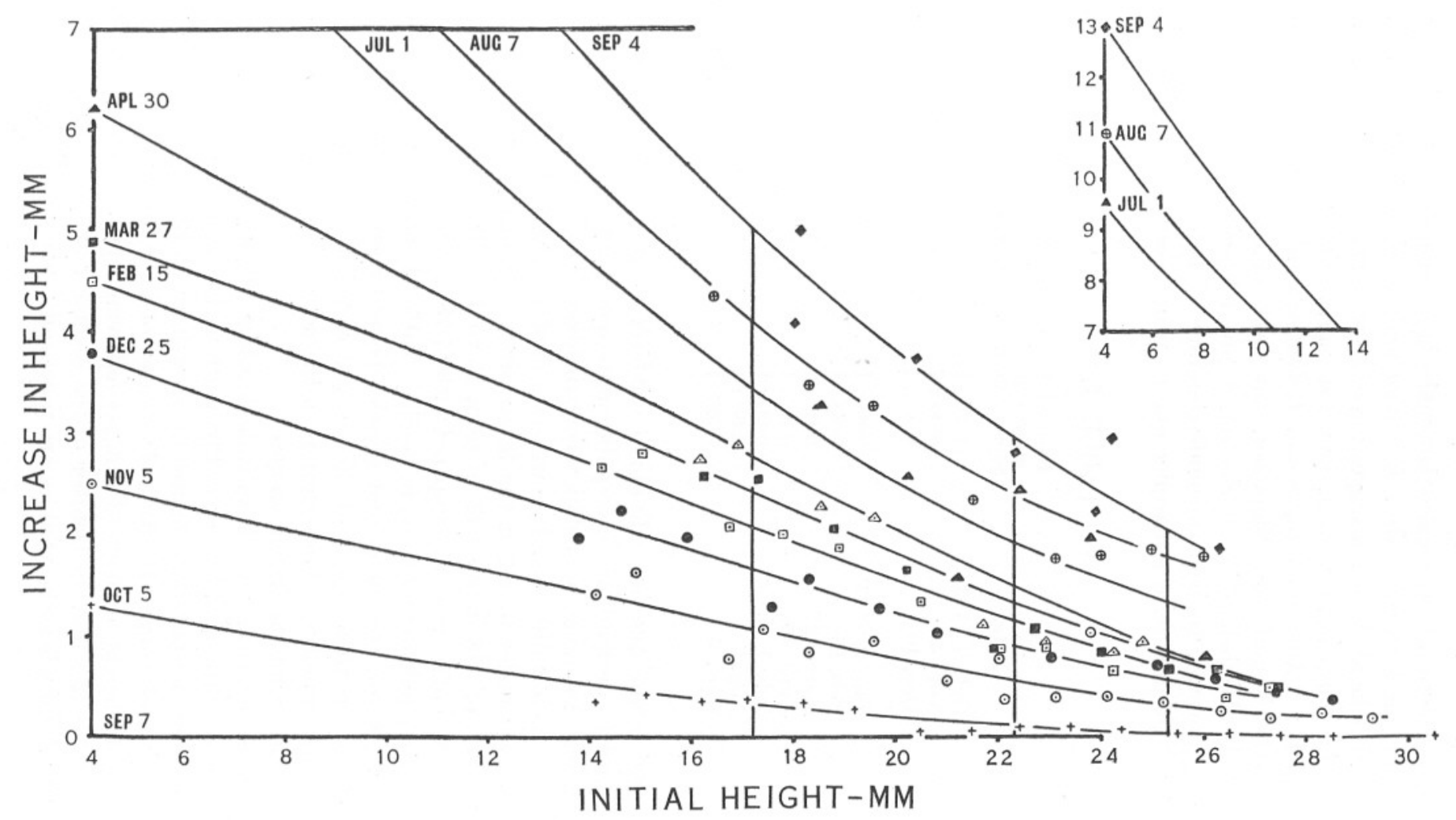

FIG. 5.-Growth of marked L. littorea at successive intervals of measurement on Drake's Island. Each point represents the mean for all individuals commencing growth within a given millimetre group. 
A greater growth-rate in females than males has been indicated in the case of two Indian Littorinas also, L. scabra and L. obesa (Sewell, 1924). On the other hand there is a suggestion of a greater rate of growth in the males of $L$. littorea, at any rate in their first year, made by Linke, who says (1933, p. 4) : "Auch die Jungen von L. littorea werden erst nach einem Jahr geschlechtsreif, das Männchen hat dann eine Schalenhöhe von $13 \mathrm{~mm}$., das Weibchen eine solche von $8 \mathrm{~mm}$. (Pelseneer, 1926)." This appears, however, to be a misunderstanding of Pelseneer's statement (p. 18): “Je dois faire remarquer que ce pénis n'est d'ailleurs jamais

\section{TABLE I.}

$\begin{array}{cc} & \begin{array}{l}\text { Ratio of } \hat{o}: \text { : } \\ \text { growth since }\end{array} \\ \text { Sept. 6, 1934. }\end{array}$

Oct. 51934.

Nov. 5

Dec. 10

Jan. 91935.

Feb. 15

March 27

April 30

July 1

Aug. 7

Sept. 4

$\begin{array}{cc}\begin{array}{c}\text { Ratio of } o: \\ \text { growth since } \\ \text { Sept. } 6,1934 .\end{array} & \begin{array}{c}\text { Number } \\ \text { of } \\ \text { specimens }\end{array} \\ (1 \cdot 48: 1) & 131 \\ 0 \cdot 90: 1 & 145 \\ 0.82: 1 & 334 \\ & \\ 0.98: 1: & 61 \\ 0.83: 1 & 97 \\ 0.91: 1 & 76 \\ 0 \cdot 84: 1 & 84 \\ 0 \cdot 60: 1 & 17 \\ 0.68: 1 & 30 \\ 0.52: 1 & 12\end{array}$

développé avant que les individus considérés aient comme dimension 13 millimètre de hauteur de coquille, alors que, pour un hauteur de 8 millimètres, des ovules sont déjà reconnaissables dans la glande génitale des 우." Such a differential growth-rate explains the preponderance of females over males found in the larger sizes. Pelseneer (1926), in an examination of 516 individuals of from 13 to 15 millimetres in height, found $50.96 \%$ of females, as compared with $67 \cdot 18 \%$ of females in a sample of 192 individuals over $2 \cdot 2 \mathrm{~cm}$. in height. Table II shows a similar condition at Trevol, the males and females being present in about equal proportions up to a height of $25 \mathrm{~mm}$., after which the proportion of females rises rapidly to three-quarters of the population. Sewell found a similar result with the Indian species.

There are practically no data available which allow of the comparison of the growth-rate of $L$. littorea at Plymouth with that in other localities. Wright (1936) has published figures for growth in the Blackwater estuary in Essex, which show a height in December of their first year of about $8 \mathrm{~mm}$., and a height of about $12 \mathrm{~mm}$. the following April. But his further figures of $21-22.5 \mathrm{~mm}$. in October of the second year, and $23 \mathrm{~mm}$. the following April when the winkles are practically two years old are read 
from size-distribution peaks which are most probably multiple, and which are based on the wholly inadequate numbers of 19, 44 and 7 individuals

\section{TABLE II.}

Mean height.

$\mathrm{mm}$.

$15 \cdot 8$

$16 \cdot 8$

$17 \cdot 8$

$18 \cdot 8$

$19 \cdot 8$

$20 \cdot 8$

$21 \cdot 8$

$22 \cdot 8$

$23 \cdot 8$

$24 \cdot 8$

$25 \cdot 8$

$26 \cdot 8$

$27 \cdot 8$

$29 \cdot 8$

$$
\% \text { of } ㅇ ㅜ .
$$

$47 \cdot 5$

$50 \cdot 0$

$46 \cdot 3$

$54 \cdot 6$

$50 \cdot 9$

$48 \cdot 1$

$45 \cdot 1$

$42 \cdot 6$

$51 \cdot 7$

$48 \cdot 7$

$59 \cdot 0$

68.9

$77 \cdot 8$

$76 \cdot 9$
No. of specimens.

202

214

317

317

320

318

315

317

311

288

251

106

36

26

\section{Total 3338}

respectively. Hayes (1929) gives some figures for growth over a short period at St. Andrews, N.B., which showed a progressive decrease in growth-rate of adult winkles with increasing height above low water.

\section{Shell Shape and Weight.}

Shell shape in $L$. littorea shows very much less variation from one locality to another than in Purpura lapillus (Moore, 1936), this being probably associated with the dispersal obtained by the pelagic eggs of the former, the young Purpura hatching and dispersing on the same ground as the adults. The spiral angle $\alpha$ (Moore, 1936, p. 72) appears to remain more or less constant up to a height of $1-1.5 \mathrm{~cm}$., and thereafter to drop fairly steadily. The value for the small shells was about $82 \cdot 6^{\circ}$, and the lowest value observed in large shells was $81 \cdot 1^{\circ}$. The apical halfangle $\theta$ appears to rise slightly to a maximum at a height of about $1-1.5 \mathrm{~cm}$., and, as in $\alpha$, to fall steadily with further increase in height. Table III shows the values of $\alpha$ and $\theta$ at a height of $2.0 \mathrm{~cm}$.

For a given height of shell, an increase in apical angle will tend to result in an increase in the shell weight, but since an increase in the spiral 
angle will tend to reduce the weight, and since these two angles vary in the same direction with increasing shell height, the weight does not show any great departure from a linear relationship with the cube of the height.

TABLE III.

\begin{tabular}{|c|c|c|c|c|}
\hline \multicolumn{2}{|c|}{ Locality. } & \multicolumn{2}{|r|}{$\alpha$} & $\theta$ \\
\hline Trevol & . & . & $32 \cdot 4^{\circ}$ & $82 \cdot 46^{\circ}$ \\
\hline Hannafore & Point, Looe & 0 & $40 \cdot 8^{\circ}$ & $81.95^{\circ}$ \\
\hline Polperro & . & . & $38.9^{\circ}$ & $82 \cdot 30^{\circ}$ \\
\hline Wembury, & , Church Reef & $\cdot$ & $40 \cdot 4^{\circ}$ & $82 \cdot 08^{\circ}$ \\
\hline Charlestou & wn & 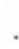 & $38 \cdot 8^{\circ}$ & $81 \cdot 72^{\circ}$ \\
\hline Drake's Is & land & . & $41 \cdot 4^{\circ}$ & $82 \cdot 10^{\circ}$ \\
\hline
\end{tabular}

Fig. 6 shows the shell weight-height relationship for the three Plymouth grounds. In Purpura lapillus a close correlation was found between sexual maturity and the changes in the fundamental shell angles, but this is not apparent in L. littorea.

\section{Maturation of the Gonads and Spawning.}

The anatomy of the gonads and genital apparatus has been described in detail by Linke (1933), and on pp. 38-40 he summarized the information extant on the eggs and the process of laying them. According to him spawning takes place in March, April and May, though in extreme cases there may be some spawning as early as January and as late as June; and he states further that eggs of $L$. littorea have been found in the plankton as early as November. Spawning takes place chiefly on the flood tide and at night. Elmhirst (1923) gives the spawning season at Millport as January to July and rarely August, and states that young appear abundantly on the shore by April. Tattersall (1920) gives the breeding season as January to June with a maximum in April and early May, and states that the males become mature in early January, but that he did not find any females with the ovary ripe until the middle of February. $\mathrm{He}$ found spent males after the beginning of April.

The results obtained from gonad examinations of winkles from Trevol are very similar (Fig. 7). No ripe females were found before early February, but between then and mid-March spawning took place rapidly, although some females not yet completely spent were still to be found at the end of May. No fully ripe males were recorded before the beginning of January, but at that time most of the males contained a certain number of apparently ripe sperm, and were presumably capable of copulating. By early February all the males were fully ripe, and in May a few spent ones were found. The curves showing the seasonal variation in 
tissue weight on the different grounds (Figs. 8, 9, 10) indicate similar results, if the spring drop in weight is taken to represent loss due to spawning. At Trevol and Drake's Island the spawning appears to commence about the beginning of December, and at the Yealm perhaps slightly earlier, although no sample was taken there in December. At Trevol, where the tissue weights of the males and females were determined

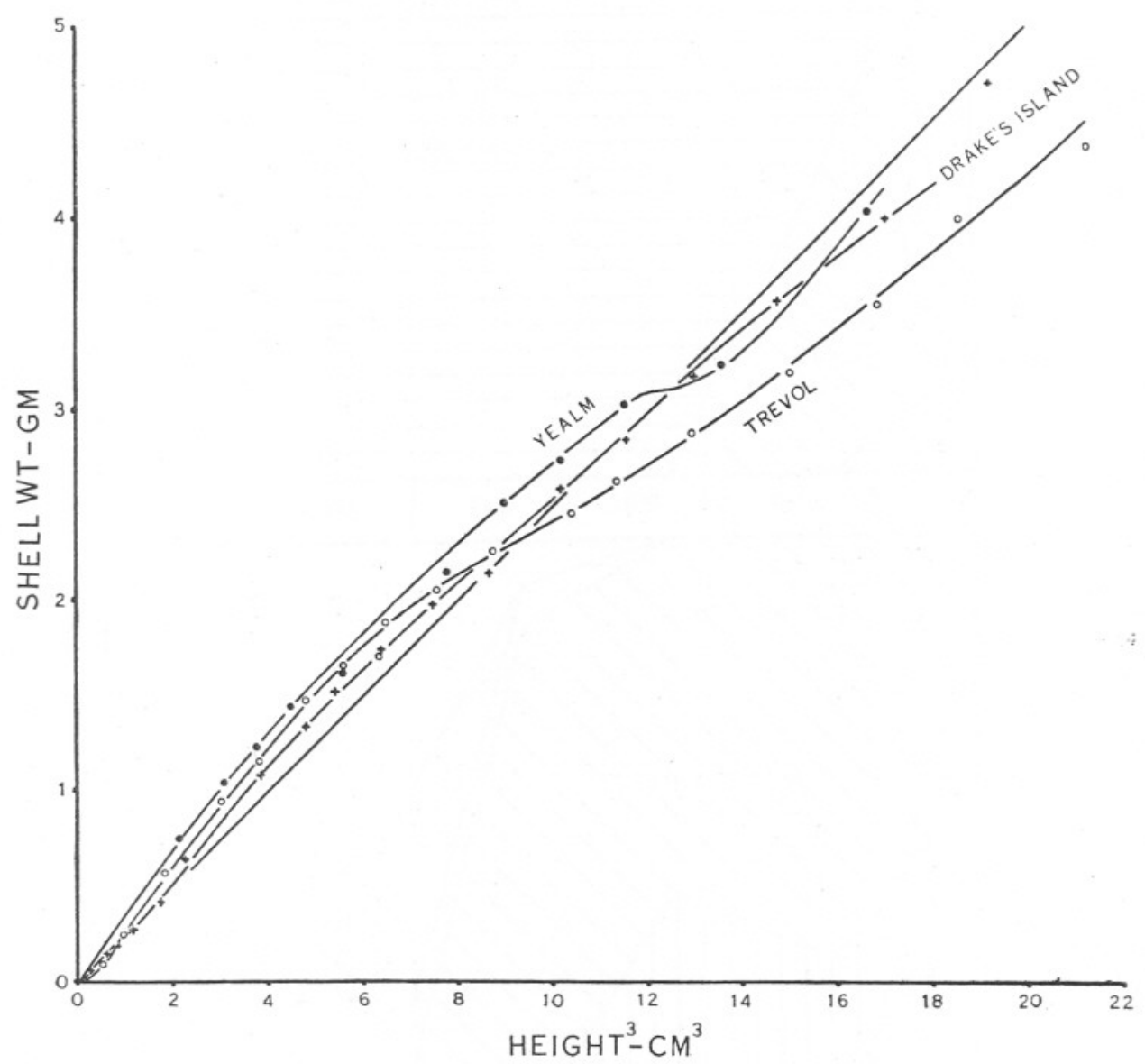

FIG. 6.-Relation of shell weight to height.

separately, the males show a drop in weight commencing about a month before the females, that is at the beginning of November, this earlier loss of weight being no doubt due to copulation which precedes spawning by a variable period. On all three grounds spawning appears from the tissue weight figures to have been practically complete by some time between mid-March and mid-April. Dr. M. V. Lebour's observations on the occurrence of the eggs and larvae of $L$. littorea in the plankton 


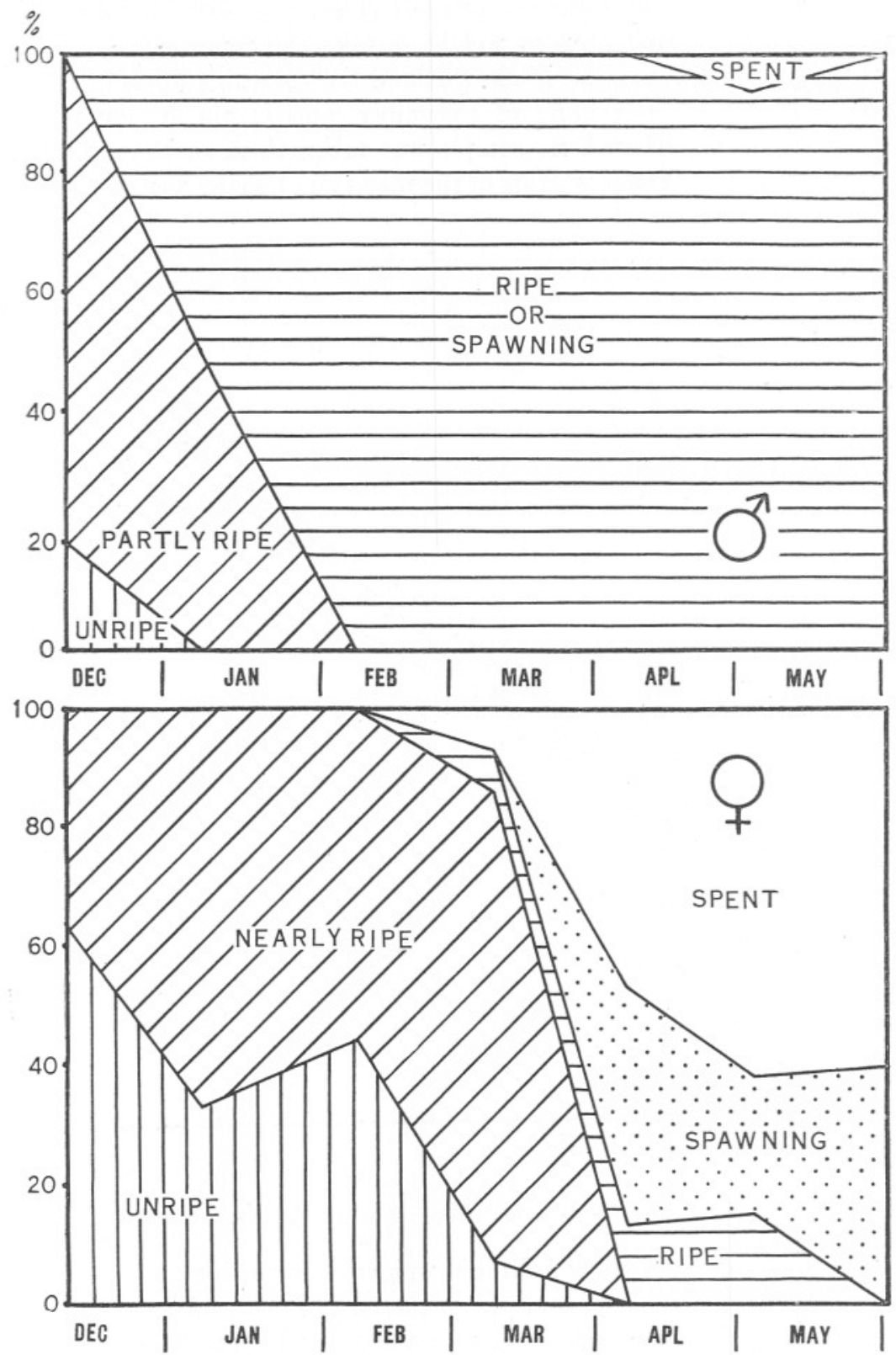

FIG. 7.-Gonad condition of $L$. littorea at Trevol in 1935-36. 
round Plymouth, confirm these dates. She says (personal communication) that the first eggs are usually seen about the middle of November, and that a few may be taken as late as June, but that the greatest numbers are in February and March. With regard to the time of settlement of the young on the shore, the 1935 brood was specially searched for with a fine sieve at Trevol on May 17 of that year and none were found, but at the next visit on July 1 they were abundant. At Drake's Island the 1936 brood was not found on the shore on April 21, and was recorded as present, but not plentiful on May 19. On June 2, 1936, they were present in very small numbers only at Trevol. About the end of May to the end of June may therefore be taken as the main period of settlement of the young on the shore, and if this is so Elmhirst's statement of the abundance of newly settled young on the shore in April is open to question.

Fig. 8 shows a curve for mean monthly temperatures for the sea off Promenade Pier, Plymouth, for the years 1912-19 (Orton, 1920), and from this it will be seen that, if we take the spawning period as falling in the months February to mid-April, the corresponding sea temperatures will be from the winter minimum of about $8^{\circ} \mathrm{C}$. to an upper limit of about $9^{\circ} \mathrm{C}$., with a small amount of earlier spawning on a dropping temperature from about $10^{\circ} \mathrm{C}$. downwards.

\section{Tissue Weights.}

The tissue weight curves in Figs. 8, 9 and 10 were obtained as follows : From all three grounds, curves were available relating tissue weight to shell height, at intervals through the year (p. 723). Curves showing shell growth during the first two years of life, as indicated by the size distribution curves, were also available for all three grounds, and for Drake's Island the growth during subsequent years could be calculated from Fig. 5. The shell height curves were therefore drawn, using the cube of the height as being likely to have an approximately linear relation to weight, and the observed tissue weights then inserted for the shell heights corresponding to the successive seasons of sampling. As shell-height curves for only the first two years were available for the Yealm and Trevol, their subsequent growth was assumed to be similar to that at Drake's Island, but less throughout in the ratio of $\frac{\text { height }(\text { Yealm })^{3}}{\text { height (Drake's I. })^{3}}=0 \cdot 46$ for the Yealm, and greater for Trevol in the ratio $\frac{\text { height } \text { (Trevol) }^{3}}{\text { height (Drake's I. })^{3}}=1 \cdot 22$ these being the observed ratios on the last dates on which accurate figures are available from size distribution curves, namely, November 11 (2nd year) for the Yealm, and July 30 (2nd year) for Trevol. It is fully realized that such figures for the third and subsequent years are only 


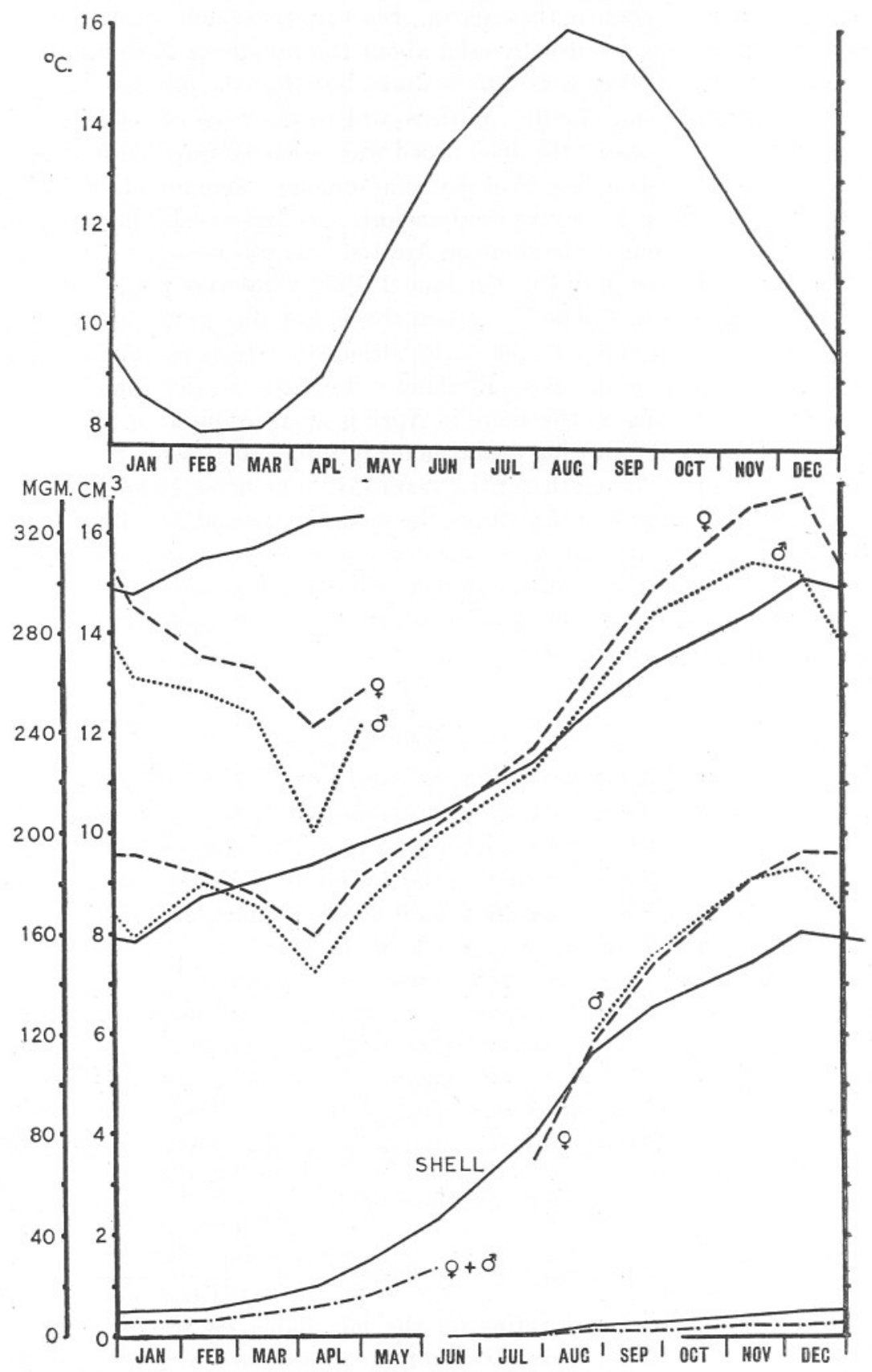

FIG. 8.-Monthly mean sea temperatures for Plymouth (1912-19); growth of the shell (height ${ }^{3}$ ) and of the tissues (dry weight) in the successive year-groups at Trevol. 
rough approximations, but the purpose of the tissue weight curves is not to show the absolute tissue weight at any given time, but rather to show its seasonal variation, and the degree of this variation at different ages relative to the shell size, and to show also the differences, if any, in the seasonal variations in tissue weight in the two sexes. For this

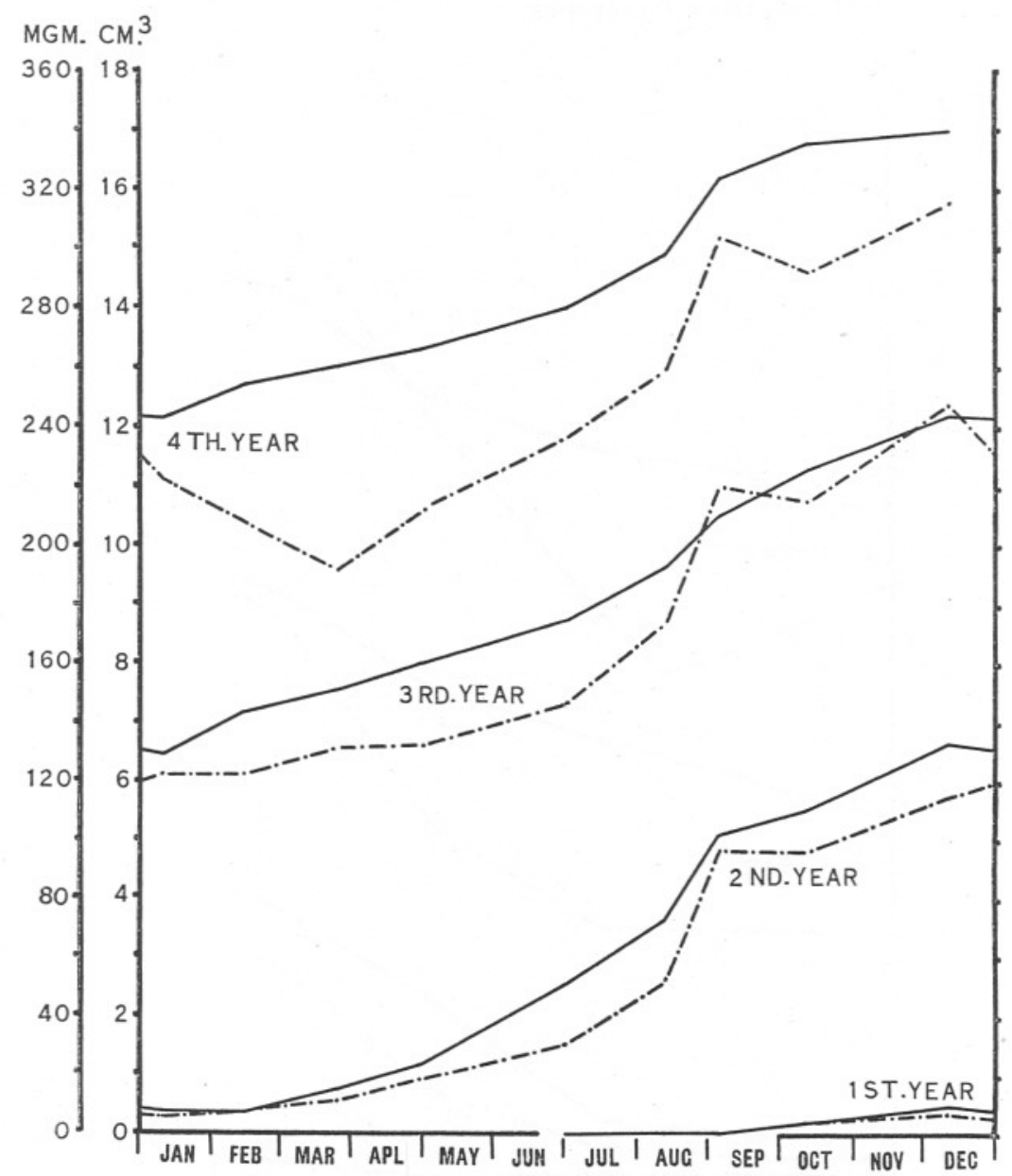

Fig. 9.-Growth of the shell $\left(\right.$ height $^{3}$ ) and of the tissues (dry weight) at Drake's Island.

the shell heights used form an adequate framework. Separate data for the males and females are available only from Trevol, and even there only above an age of one year, the sexes not having been found separable externally in the younger stages. No account has been taken of the observation that the females grow somewhat faster than the males, 
since it would only have added complexity to the diagrams, but if the difference in growth of the two sexes is the same at Trevol as it is at Drake's Island, then it may be taken that the tissue weights for the females should be about $10 \%$ greater, and those for the males about $10 \%$ less throughout than those shown. This, however, has no effect on the general deductions drawn from the graphs.

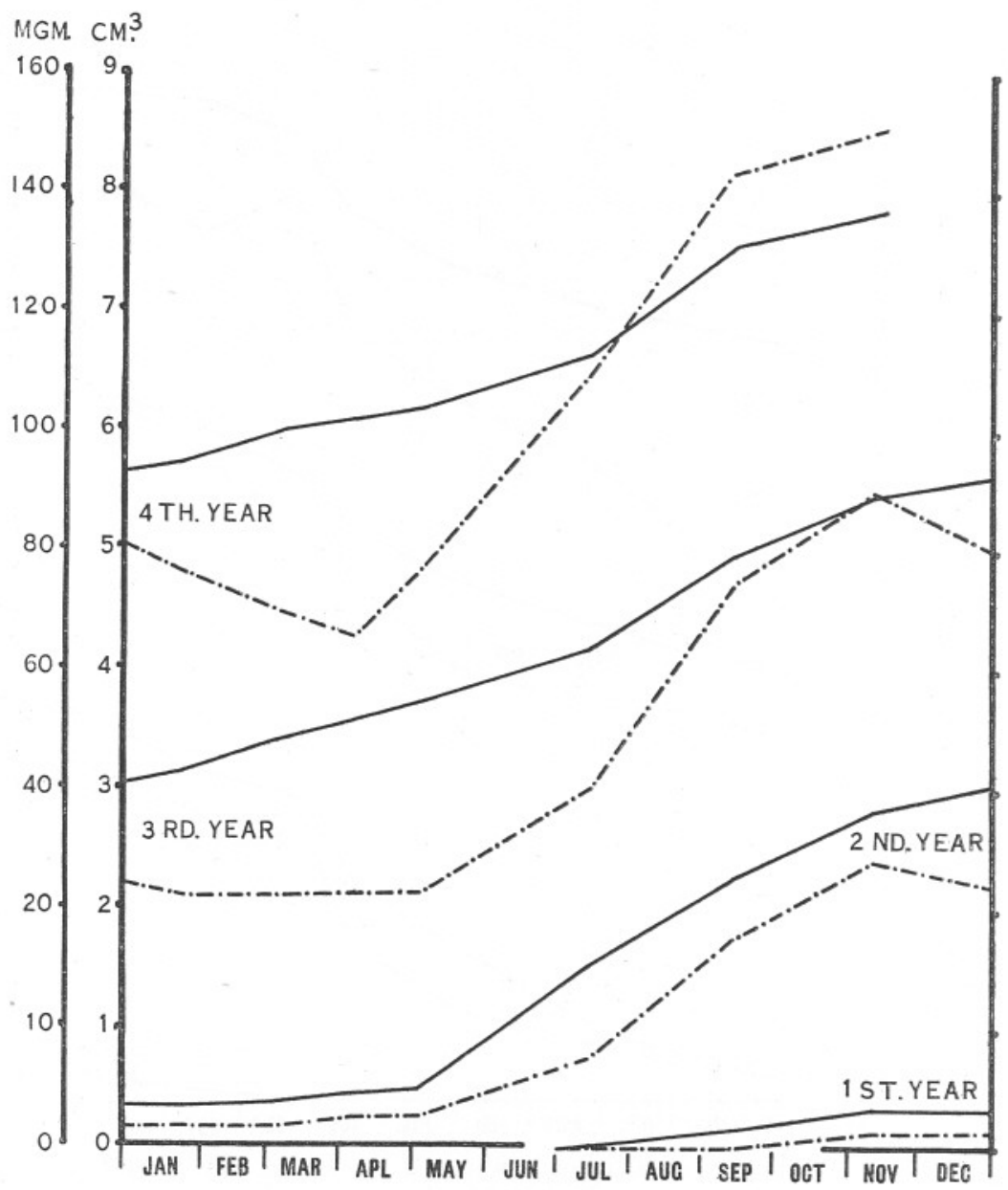

Fic. 10.-Growth of the shell (height ${ }^{3}$ ) and of the tisstes (dry weight) at the Yealm.

The relatively slow growth-rate of the Yealm winkles is rendered even more noticeable when, instead of being recorded in terms of height, it is shown in the more natural units of either tissue weight or height ${ }^{3}$. It is then seen that the growth at the Yealm is only about half that of Trevol and Drake's Island. In shell growth then, Drake's Island and 
Trevol are more or less similar, in contradistinction to the Yealm. With regard to tissue growth, however, there is a point in which Drake's Island and the Yealm differ markedly from Trevol. It was found by examination of samples of winkles from Drake's Island in December, 1935, and from Trevol and the Yealm in March, 1936, that on all grounds the 1935 brood, which were then 3-6 months old (since settling), were immature sexually, while the 1934 brood, then 15-18 months old, were all definitely mature. The tissue weight figures for Trevol confirm this, showing a marked drop in weight in the second spring, indicating presumably a considerable spawning when 18 months old, but on the other two grounds, and in particular on Drake's Island, there is indication of very much less spawning, and it is not until the winkles are $2 \frac{1}{2}$ years old that the loss of weight at spawning is really marked, and even then the weight loss is not as great as it is at a corresponding age at Trevol. The latter locality therefore appears to be markedly superior to the other two so far as production of larvae is concerned.

\section{Mortality Rate.}

The size distribution curves in which it is possible to separate the numbers of shells in the first, and sometimes also the second year groups from those of all older groups, allow of the calculation of the rate of mortality in those groups. This is, of course, possible only if the sample is an adequate one so far as those groups are concerned. After the shells are about one centimetre in height, the sampling may be taken to be adequate on all grounds. With the method of sampling used at Trevol, the first year groups also may be taken to be adequately sampled there from the spring of 1935 on. The method also assumes that the spat-fall is similar in different years. While this is almost certainly not strictly true, yet the general impression obtained is that the wide fluctuations observed in the spat-fall in different years in many lamellibranchs does not occur in this species, and that one year is substantially similar to another, at any rate in this region.

At the time when the young post-larval winkles are settling on to the shore, the loss by death will be to some extent counteracted by gain from the plankton so that the mortality rate cannot be estimated by this method, but by the end of July the gain from the plankton may be assumed to be negligible. In the two samples from Trevol on July 30 and August 28, 1935, the ratios of the numbers of 1935 group shells to all older ones was $8 \cdot 6: 1$ and $8 \cdot 4: 1$ respectively. Taking $8 \cdot 5: 1$ as the mean value, then out of every 950 shells of all ages at that time, 850 are first year, and 100 are in their second or subsequent year. Of these hundred, $100 \times \frac{1 \cdot 4}{2 \cdot 4}$ or 58 are in their second year $(1 \cdot 4: 1$ is the ratio in the 
second and subsequent years, see below). That is to say that, if the JulyAugust rate were maintained for a year, only 58 animals would survive out of an initial 850 newly settled young. This gives a mortality rate of 94 per cent per annum for the months July and August, but if during this time there was any further settlement from the plankton, then the rate must be even higher, and during the period immediately after settlement the rate almost certainly is higher. It seems desirable to omit the samples in September, 1935, and in May, 1936, as being obviously not representative. Doing this, and working out the ratio of the 1935 group to all older shells for all samples from Trevol from September, 1935, to June, 1936 , the mean value for the ratio comes to $1 \cdot 7: 1$, and similarly, taking the mean value of the ratio of numbers in the 1934 group to all older ones in the period July, 1935, to June, 1936, the result is $1 \cdot 4: 1$. The ratios therefore drop from 8.5:1 in the first few months, through $1 \cdot 7: 1$ for the remainder of the first year to $1 \cdot 4: 1$ in the second year, and this may probably be taken as a mean figure for all older shells also. Translating these ratios into percentage mortalities, the results are 94 per cent per annum or more for the first two months, 66 per cent for the rest of the first year, and 57 per cent thereafter. Sampling on Drake's Island was less adequate, and a figure can be obtained for the second and subsequent years only, the ratio here being $1.85: 1$, corresponding to a mortality rate of 65 per cent, which, within the limits of experimental error, may probably be taken as about the same as at Trevol. At the Yealm the results are extraordinarily different. The mean value of the ratio here for the 1935 group for the period July, 1935, to March, 1936, was $0.92: 1$, corresponding to a mortality rate of 82 per cent per annum, while for the older individuals of 15 months old and more, the mean value was $0 \cdot 30: 1$, or only 23 per cent per annum.

Although these are only approximate figures, the difference between 23 per cent at the Yealm and 55-65 per cent on the other two grounds is too large not to be significant. It cannot be accounted for by collecting by fishermen, since such little collecting as there is takes place at Trevol and the Yealm, and not on Drake's Island. The only internal enemies known to have any serious effect on winkles are cercariae, and for these Rees's figures $(1936$, p. 358) show a total infection for all species of cercariae of only 10 per cent at Drake's Island and 2 per cent at Trevol. Even if the Trevol percentage is rather low, it is far too small to account for the observed mortality, and none of the cercariae are, according to Rees, likely to be fatal to the winkle, the only definitely fatal species, Cercaria emasculans, not having been found on these grounds. It must, however, be noted that among very large winkles the percentage infection by cercariae is much higher. At Aberystwyth (Rees, 1935) the total infection by all species in winter was $4-5$ per cent, probably somewhat 
more in summer, and $C$. emasculans accounted for only about a third of this, so that there also it would be a negligible factor in the general mortality. We are forced therefore to look for either a limiting environmental factor or enemies such as birds or fish which might kill the winkles in considerable numbers, and at present the available information on these is very scanty.

\section{Summary of Conditions on the Three Grounds.}

\begin{tabular}{|c|c|c|c|}
\hline & Trevol. & Drake's Island. & Yealm. \\
\hline Level. & Mid-tide. & $\begin{array}{l}\text { Mid-tide to } \\
\text { between mean } \\
\text { low water of } \\
\text { ne a p a nd } \\
\text { springs. }\end{array}$ & $\begin{array}{l}\text { Mean low water } \\
\text { of spring tides. }\end{array}$ \\
\hline Habitat. & Mud. & Stones. & Stones. \\
\hline Growth-rate. & $\begin{array}{l}\text { About the same } \\
\text { as on Drake's } \\
\text { Island. }\end{array}$ & 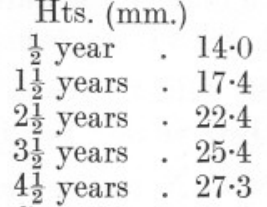 & $\begin{array}{l}\text { Much less than } \\
\text { on Drake's } \\
\text { Island. }\end{array}$ \\
\hline $\begin{array}{l}\text { Yearly variation } \\
\text { in growth-rate. }\end{array}$ & $\begin{array}{l}\text { Growth-rate pro- } \\
\text { gressively less } \\
\text { in 1934-35-36. }\end{array}$ & $\begin{array}{l}\text { Growth-rate pro- } \\
\text { g r e s s i v e l y } \\
\text { greater in 1934- } \\
35-36 .\end{array}$ & $\begin{array}{l}\text { Grow } \mathrm{th}-\mathrm{rate} \\
\text { approximately } \\
\text { the same in } \\
1934-35(-36 ?) \text {. }\end{array}$ \\
\hline $\begin{array}{l}\text { Age at sexual } \\
\text { maturity. }\end{array}$ & 18 months. & 18 months. & 18 months. \\
\hline $\begin{array}{l}\text { Age at first con- } \\
\text { siderable spawn } \\
\text { output. }\end{array}$ & $1 \frac{3}{4}$ years. & $2 \frac{3}{4}$ years. & $2 \frac{3}{4}$ years. \\
\hline Mortality rate. & $57 \%$ & $65 \%$ & $23 \%$ \\
\hline
\end{tabular}

\section{REFERENCES.}

Elmhirst, R. 1923. Annual Report of the Scot. Mar. Biol. Assoc. for the year 1922, pp. 1-47.

Hayes, F. R. 1929. Contribution to the Study of Marine Gastropods. III. Development, Growth and Behaviour of Littorina. Contr. to Canad. Biol. and Fish., N.S., Vol. IV, No. 26, pp. 1-18.

Linke, O. 1933. Morphologie und Physiologie des Genitalapparates der Nordseelittorinen. Wiss. Meeresuntersuch., Abt. Helgoland, Bd. XIX, Abh. Nr. 5, pp. 1-60.

Moone, H. B. 1936. The Biology of Purpura lapillus. I. Shell Variation in Relation to Environment. Journ. Mar. Biol. Assoc., N.S., Vol. XXI, pp. 61-89. 
Orton, J. H. 1920. Sea-Temperature, Breeding and Distribution in Marine Animals. Journ. Mar. Biol. Assoc., N.S., Vol. XII, pp. 339 366 .

Pelseneer, P. 1926. La Proportion relative des Sexes chez les Animaux et particulièrement chez les Mollusques. Mém. Acad. Roy. Sci. Belg., Cl. Sci., pp. 1-258.

Rees, W. J. 1935. The Anatomy of Cercaria buccini Lebour. 1911. Proc. Zool. Soc. London, Part I, pp. 309-312.

1936. The Effect of Parasitism by Larval Trematodes on the Tissues of Littorina littorea (Linné). Proc. Zool. Soc. London, Part 2, pp. 357-368.

Sewell, R. B. S. 1924. Observations on Growth in certain Molluscs and on Changes correlated with Growth in the Radula of Pyrazus palustris (with a note on the radula by the late N. Annandale). Rec. Ind. Mus., Vol. XXVI, pp. 529-557.

Tattersall, W. M. 1920. Notes on the Breeding Habits and Life History of the Periwinkle. Sci. Invest. Fish. Br. Ire., No. 1, pp. 1-11.

Waters, A. H. 1890. Notes on Marine Mollusca in Captivity. Science Gossip, p. 108.

Wright, F. S. 1936. Report on the Maldon (Essex) Periwinkle Fishery. Fish. Inv. London, Ser. II, Vol. XIV, No. 6, pp. 1-37. 